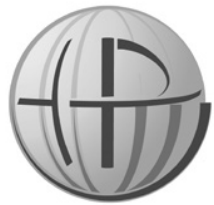

JAN RoKita

Akademia Ignatianum w Krakowie Instytut Nauk o Polityce i Administracji

janmrokita@gmail.com

DOI: $10.35765 /$ HP.1980

Horyzonty Polityki

2020, Vol. 11, No 35

OPEN ACCESS

\title{
Błąd Izokratesa \\ (czyli o konserwatywnej polityce kulturalnej)
}

\section{Streszczenie}

CEL NAUKOWY: Celem artykułu jest zaprezentowanie idei polityki kulturalnej, wolnej zarówno od nadmiernej interwencji zbiurokratyzowanego państwa, jak też - z drugiej strony - od wpływów koterii kulturalnych.

PROBLEM I METODY B ADAWCZE: Metoda badawcza polega na odwołaniu się do idei „etatyzmu kulturalnego", sformułowanej przez starożytnego retora Izokratesa. Autor mówi o „błędzie Izokratesa”, który jego zdaniem polegał na postulacie interwencji polis w kształtowanie politycznego i duchowego życia Greków. Odnosi tę ideę do analizy polityki kulturalnej w świecie zbiurokratyzowanych demokracji współczesnych. Na podstawie tej analogii przeprowadza swój krytyczny wywód.

PROCES WYWODU: Początek wywodu nawiązuje do protekcjonizmu kulturalnego w polityce państw współczesnych. Następnie analizie zostaje poddane pojęcie politycznego humanizmu, zaczerpnięte z Paidei Wernera Jaegera. Kolejnym krokiem jest krytyka konstruktywizmu Izokratesa, któremu przyświecała idea odnowienia Areopagu jako wychowawcy ludu w politei. Te dwie idee potraktowane zostaną w tekście jako niemożliwe do urzeczywistnienia we współczesności.

WYNIKI ANALIZY NAUKOWEJ: Zasadniczym wnioskiem płynącym z przeprowadzonych analiz jest teza, iż współczesne procesy globalizacji kultury obniżają standardy edukacyjne. Tymczasem właściwymi celami polityki kulturalnej państwa powinna być integracja wspólnoty, a także reprodukcja elit. 
Autor twierdzi, że ani „polityczny humanizm”, ani też „,kulturalny etatyzm” nie mogą tych celów właściwie realizować. Pierwszy uległ bowiem współczesnej zbiurokratyzowanej polityce kulturalnej, a „,błąd Izokratesa” nie daje współcześnie nadziei na urzeczywistnienie idei neoizokratejskiej.

WNIOSKI, INNOWACJE, REKOMENDACJE: Z powyższego wynika, iż jedynym rozsądnym wyjściem z sytuacji wydaje się celowa działalność państwa, które swą politykę kulturalną ukierunkowuje na konkretne cele, wystrzegając się etatyzmu kulturalnego, w czym może go wesprzeć wolny rynek. Autor nazywa taką strategię pseudo-paideią.

\title{
SŁOWA KLUCZOWE:
}

kultura, polis, demokracja, etatyzm, globalizacja

\author{
THE ERROR OF ISOCRATES \\ (ABOUT CONSERVATIVE CULTURAL POLICY)
}

RESEARCH OBJECTIVE: The aim of the article below is an idea of the policy of culture, free both from the excessive intervention of the bureaucratic state and from the influence of the cultural coteries.

THE RESEARCH PROBLEM AND METHODS: The research problem is to call an idea of the "cultural etatism" formulated by an ancient rhetorician Isocrates. The author speaks about an "error of Isocrates", which - in his opinion - relied on the postulate of shaping the political and spiritual life of Greeks by the intervention of the polis. He applies this idea to an analysis of the policy of culture in the contemporary bureaucratic States. He carries out his argumentation on the ground of this analogy.

THE PROCESS OF ARGUMENTATION: In the beginning the argument refers to the protectionism in the politics of the contemporary States. Then the object of examination is the notion of the political humanism, used by Werner Jaeger in his "Paideia". The next step is a critique of the constructivism of Isocrates, who was guided by the idea of reconstructing Areopag as an educator of people in polis. Those two ideas will be handled as of no use in the context of the present time.

RESEARCH RESULTS: The crucial conclusion of the argumentation is the thesis that the present-day processes of globalization of culture debase the standards of education, whereas the suitable aims of cultural policy should be an integration of the community and also the reproduction of elites. The author argues that neither the political humanism nor the "cultural etatism are able to 
Błąd Izokratesa (czyli o konserwatywnej polityce kulturalnej)

realize properly these aims. The first has been devastated by the present-day bureaucratic policy of culture, whereas the "error of Isocrates" makes impossible nowadays the realization of neoisocratic idea.

CONCLUSIONS, INNOVATIONS AND RECOMMENDATIONS: Therefore the only reasonable way out of this situation seems to be the intentional activity of State, which aims its cultural policy to the specific objects, that is to say, which avoids cultural etatism and has its support in the free market. The author calls this strategy a "pseudo-paideia".

\section{KeYwORDS:}

culture, polis, democracy, etatism, globalization

1. We współczesnej Europie kultura otrzymała status działu administracji publicznej, a jej „popieranie" uchodzi za niekwestionowaną powinność aparatów biurokratycznych nowoczesnego państwa. W krajach demokratycznych, w ciągu wielu powojennych dziesięcioleci, kwestia „popierania kultury” przez rządy w zasadzie wyjęta została spod poważniejszych kontrowersji ideowych i politycznych, a praktyczną granicą państwowej interwencji w tej dziedzinie były niemal wyłącznie limity publicznych budżetów. W powojennej Europie powszechnie zwykło się bowiem sądzić, że za pomocą „popierania kultury" i kulturalnej wymiany można będzie zbliżyć nienawidzące się dotąd nawzajem narody, a przez to łatwiej osiągnąć polityczny cel trwałego pokoju. Co najwyżej można więc było słyszeć skargi tzw. „ludzi kultury" (który to termin rozumiem tutaj jako członków poszerzającej się liczebnie grupy interesariuszy państwowej polityki kulturalnej), iż w porównaniu z innymi wydatkami państwa publiczne fundusze przeznaczone na kulturę są zbyt nikłe. Można też - przynajmniej w niektórych krajach - obserwować powstawanie swego rodzaju „narodowych strategii” polityki kulturalnej, których celem miała być ochrona krajowej produkcji kulturalnej przed zalewem produktów kultury amerykańskiej, rosnącym w miarę spontanicznego postępu globalizacji. Takie „narodowe strategie” naśladowały $\mathrm{w}$ istocie dobrze znane instrumentarium ekonomicznego protekcjonizmu, obliczonego na wyhamowanie albo co najmniej korektę samoregulacyjnych mechanizmów rynku, tyle że w zastosowaniu do produkcji i usług w dziedzinie kultury. Najczęściej zatem chodziło 
o utrudnienia, tzw. „bariery pozataryfowe” dla usług i produkcji obcych, oraz o różne formy pomocy publicznej - dla krajowych. Co prawda strategie takie $\mathrm{z}$ istoty rzeczy wchodziły $\mathrm{w}$ kolizję ze spontanicznymi trendami rynkowego kapitalizmu, ale - co nie bez znaczenia - ich przesłanką wyjściową nie była $\mathrm{z}$ reguły walka $\mathrm{z}$ rynkiem, a raczej intencja wykazania się przez rządy „patriotyzmem kulturalnym". Rynek stawał się w takich razach niejako przypadkowym albo, w każdym razie, co najwyżej „ubocznym” wrogiem państwowej polityki kulturalnej. Nie jest zapewne przypadkiem, że $\mathrm{w}$ demokratycznej Europie w tego typu narodowych programach przodowała zazwyczaj Francja, której politycy, wychowani na ideach gaullistowskich, traktują Amerykę jako polityczne zagrożenie dla interesów własnego kraju, bynajmniej nie tylko, ani nawet nie przede wszystkim w dziedzinie kultury. Dlatego właśnie Paryż przeforsował w Unii Europejskiej na przykład regułę całkowitego wyłączenia „przemysłu kulturalnego" spod negocjacji nad (niedoszłym w końcu do skutku) traktatem o transatlantyckim wolnym handlu. Kwestia zasadności i podstaw państwowej interwencji w sferze kultury stała się szczególnie paląca aktualnie w Polsce, a to dlatego, iż rządząca dziś konserwatywna prawica zdaje się w sprawczości państwa (i to rozumianego wyłącznie jako rząd centralny) upatrywać jedyne remedium na coraz bardziej agresywnie pleniące się w kulturze trendy irracjonalne, immoralistyczne i antyreligijne.

2. Polityka „interwencjonizmu państwowego" w dziedzinie kultury wymaga jednak uprzedniego namysłu nad kondycją współczesnego państwa i jego realnego potencjału do podejmowania takiej interwencji. Bez wątpienia państwo oddziałuje najpełniej na umysły i dusze swoich obywateli wtedy, gdy istnieje organicznie przynajmniej względna harmonia pomiędzy kulturą a polityka, co znaczy, że to w państwie w naturalny sposób wypełniają się ludzkie ideały życiowe, a uczestnictwo w życiu publicznym decydująco kształtuje charakter obywatela. Służba publiczna, w różnych swoich formach, jest wtedy szczególnie pożądaną drogą kariery życiowej, oświata w naturalny sposób jest miejscem przekazu wartości wspólnoty i jej tradycji patriotycznej, uniwersytet zaś (jak skądinąd zaplanował go Humboldt) - miejscem ochrony i rozwoju kultury narodowej. Na dobrą sprawę żadna specjalna "polityka kulturalna" - rozumiana 
jako celowa interwencja w sferę kultury - nie jest wtedy potrzebna; wystarcza bowiem samo tworzenie i utrzymywanie przez państwo odpowiednich instytucji publicznych, w których mogłoby się toczyć „narodowe” życie umysłowe i kulturalne. Ten ideał klasycznej harmonii pomiędzy człowiekiem i państwem, polityką i kulturą Werner Jaeger (pisząc o greckiej paidei) nazwał mianem „politycznego humanizmu (Jaeger, 2001, s. 141). Wedle Jaegera stosunkowo najpełniej urzeczywistnił się on we wczesnogreckiej polis sprzed wojny peloponeskiej i rozpadł już w końcówce epoki klasycznej, czego świadectwem jest fakt, iż wielcy filozofowie tamtego czasu poddają druzgocącej krytyce ustrój polis oraz samą istotę ówczesnego życia politycznego. Zafascynowany tym ideałem Hegel odnalazł we wczesnej Grecji „obraz młodzieńczej świeżości życia duchowego”, polegający właśnie na tym, że: „państwo, rodzina, prawo, religia są jednocześnie celami indywidualności, ta zaś jest indywidualnością tylko dzięki tym właśnie celom" (Hegel, 1958, t. II, s. 10).

Dylemat polityczny, jaki niesie ze sobą destrukcja ideału „politycznego humanizmu", dobrze obrazuje mowa zatytułowana Areopagityk, napisana jeszcze u końca epoki klasycznej przez Izokratesa - słynnego krytyka Platona, retora i konserwatystę, który jako swoją misję traktuje odbudowę wpływu polityki na kulturę w całkiem nowych warunkach (Isocrates, 2012). Izokrates obserwuje Ateny w dobie schyłku drugiego Związku Morskiego, kiedy nie tylko upada ich znaczenie polityczne, ale zarazem szerzy się polityczna demagogia i korupcja, apogeum osiągają namiętności partyjne, a wśród obywateli zanika pobożność i poczucie wstydu. Zły ustrój, zła polityka i powielane publicznie złe wzorce psują myśli i mowę obywateli, i nie ma takiej politycznej siły, która by temu mogła przeciwdziałać. Kultura zaczyna się powoli wycofywać do izolowanych od państwa akademii, gdzie coraz częściej rozważania nad problemami wspólnoty ustępują namysłowi i studiom nad indywidualnymi drogami do doskonałości; kulminacją tego procesu stanie się już za niedługi czas duchowa dominacja szkoły stoików. Izokrates jest doskonale świadom tego, że zwykłe odtworzenie stanu utraconej harmonii państwa i kultury nie jest już możliwe, gdyż popsuty ustrój stworzył nowy typ "popsutych" obywateli. Jako konserwatysta proponuje zatem "mechanicznie" odtworzyć to, co „organicznie” zostało utracone. Domaga się więc, aby państwo rozpoczęło świadomą i celową, 
a więc w jakimś sensie "sztuczną", interwencję w obszarze kultury, obliczoną na zmienienie czy lepiej nawet powiedzieć - ulepszenie obywateli. Postuluje zatem nic innego, jak rozpoczęcie interwencjonistycznej polityki kulturalnej, w takim dokładnie sensie, w jakim dwadzieścia trzy wieki później będzie ją rozumiał choćby konserwatysta T.S. Eliot - jako rozumną państwową pracę nad „udoskonalaniem ludzkiego umysłu i ducha” (Eliot, 2007). A ponieważ Izokrates - jak większość starożytnych - jest przekonany, że „duszą państwa jest jego ustrój” (Isocrates, 2012, s. 3), chce więc zacząć ów proces ulepszania człowieka od odbudowy dawnego Areopagu, który (tak jak po reformach Solona) stałby na straży przestrzegania moralności, obyczajów i praw. Izokrates jest konserwatywnym konstruktywista, któremu wydaje się, że świadomy projekt państwowej polityki kulturalnej, wspartej reformą ustroju, miałby moc wychować dorosłych ludzi w takim samym stopniu jak małe dzieci, i to nawet całkiem na przekór wiejącym wiatrom historii, o ile tylko udałoby się odbudować (jak się wyrazi Jaeger) „władzę dozorującą państwa”. „Tak jak inne kraje hodują wspanialsze od nas owoce, drzewa i zwierzęta, tak w ten sam sposób my jesteśmy w stanie tworzyć i chować ludzi, nie tylko umiejących mówić i działać, ale nadto wybitnych w męstwie i cnocie" (Isocrates, 2012, s. 18-19).

3. Kwestia polityki kulturalnej zaczęła się komplikować jeszcze wydatniej, odkąd Europa (choć nie tylko ona) stała się przestrzenią nasilającego się politycznego "sporu o kulturę", tu i ówdzie nazywanego nawet „,wojną kulturową". Co prawda celem tych uwag nie jest w żadnym razie próba zdefiniowania natury tego wieloaspektowego sporu, jednak bez wzięcia jego pod uwagę trudno byłoby we współczesnych okolicznościach realistycznie zastanawiać się nad sensem jakiejkolwiek polityki kulturalnej. Bez wątpienia zarzewiem owego sporu stały się nadmierne uroszczenia, okazywane zwłaszcza w ciagu ostatnich dwóch dekad przez coraz bardziej dominującą ideologię kulturalna, kwestionującą zdolność czy to jednostki, czy też wspólnoty politycznej do racjonalnego namysłu i wiążącego dla nich samych rozstrzygania kwestii dotyczących prawdy, dobra i piękna. Wedle upowszechniających się współczesnych teorii kultury nieuprawnione są nie tylko wszelkie formy tradycyjnego przekazu norm, ocen i wartości, gdyż stanowią one nic innego jak wyraz chęci „politycznego panowania” 
oraz „ideologicznej przemocy”, ale w gruncie rzeczy - równie nieuprawniona jest jakakolwiek forma racjonalnej krytyki owej tradycji, ponieważ „,sam rozum jest kłamstwem i dopiero demaskując to kłamstwo pokazujemy represyjność tkwiącą u podłoża zachodniej kultury" (by streścić celny opisu tego fenomenu przez Rogera Scrutona; tenże, 2010, s. 96). Dopóki tego rodzaju poglądy zdobywały uznanie w kręgach akademickich nie stanowiło to jakiegoś wielkiego problemu dla polityki kulturalnej prowadzonej przez państwa. Jednak u początków XXI wieku tego rodzaju ideologia, przez Scrutona nazywana „kulturą sabotażu” (albo czasem nawet bardziej dosadnie - „zorganizowaną bezczelnością"), zaczęła się przekształcać w coś na kształt kanonu światopoglądowego obowiązującego w kręgu "ludzi kultury", w międzynarodowych korporacjach, instytucjach europejskich, a stopniowo także wewnątrz krajowych biurokracji odpowiedzialnych za politykę kulturalną. Podporządkowujący się z natury rzeczy "duchowi czasu” demokratyczni politycy godzili się z czasem na to, aby z nauczania humanistyki stopniowo eliminować stare "Great Books", uniwersytety zacząć przekształcać w praktyczne kursy społecznie przydatnych (a czasem także mało przydatnych) zawodów, a instytucje kulturalne finansowane $z$ funduszów publicznych przekazywać w ręce intelektualnych, a często także artystycznych hochsztaplerów, zorganizowanych w postaci wpływowego lobby „ludzi kultury". Silne polityczne oddziaływanie tego trendu sprawiło, że dla dowolnego funkcjonariusza publicznego pracującego na niwie kultury (akademickiego profesora, nauczyciela, kuratora sztuki czy dyrektora teatru) rzeczą coraz bardziej wstydliwą stało się pozostawanie uporczywym wyznawcą zwykłego rozumu, skoro czołowi ideolodzy współczesnej kultury uznali go za oświeceniowy przesąd, po czym ironicznie zdezawuowali.

Nasza wspólnota, wspólnota liberalnych intelektualistów świeckiego nowoczesnego Zachodu, pragnie zachować zdolność wyjaśniania post factum każdej zmiany poglądów

- pisał jeden z owych ideologów Richard Rorty.

Chcemy zachować zdolność do, by tak rzec, usprawiedliwiania się przed sobą - takimi, jakimi byliśmy wcześniej (...) Dlatego musimy twierdzić, że „istnieje tylko dialog", tylko "my" i odrzucić ostatnie pozostałości ponadkulturowej racjonalności (Rorty, 1999, s. 47, 52). 
Faktyczny podbój instytucji publicznych przez tego rodzaju doktrynę sprawił, że samo państwo zaczęło się stawać nieuświadomionym narzędziem ",anty-rozumu”, czyli zepsucia umysłu i ducha swoich obywateli. W miejsce klasycznego politycznego ideału paidei wciskać się zaczęła do polityki praktyka dokładnie przeciwna, niegdyś określona przez retora Izokratesa mianem paideneie. Sprzeciw, który w końcu pojawił się wobec tego trendu i wkrótce przybrał całkiem polityczne kształty, otworzył w Europie (także w Polsce) okres coraz bardziej burzliwego politycznego „sporu o kulturę", a współczesna polityka kulturalna znalazła się w swoistym oku ideologicznego cyklonu. Cała rzecz nabrała jeszcze ostatnio iście rewolucyjnego kolorytu, po tym jak w licznych krajach podburzona tłuszcza przystąpiła do obalania pomników, symbolizujących kulturową ciągłość przekazu norm, ocen i wartości świata zachodniego.

4. Realia polskie początku XXI wieku są zapewne jeszcze o wiele bardziej odległe od ideału "politycznego humanizmu” niźli grecka polis czasów Izokratesa, wszelkie zaś próby prowadzenia interwencjonistycznej polityki kulturalnej wikłają się nieuchronnie w zaogniony "spór o kulturę". Liberalna polityka prowadzona po odzyskaniu niepodległości w 1989 r. w zasadzie porzuciła program „doskonalenia ludzkiego umysłu i ducha" (by jeszcze raz odwołać się do Eliota), koncentrując swoje ambicje w dziedzinie kultury na umasowieniu kształcenia i dostępu do dóbr kultury oraz promocji kulturowej różnorodności. Tym samym właściwą misję polityki kulturalnej przejął po części rynek, czyli rozrastający się w nowoczesnej gospodarce sektor „produkcji kulturalnej” i „usług kulturalnych”, po części zaś coraz bardziej wpływowe grupy interesów złożone $\mathrm{z}$ „ludzi kultury". Podobnie jak w całej gospodarce, liberalne państwo pozostawiło dla siebie dwie w miarę neutralne aksjologicznie role: regulatora, który tworząc normy prawne określa zakres „urynkowienia” kultury i reguły gry na tym rynku, oraz właściciela przeważającej liczby instytucji, finansowanych w części albo w całości przez rząd centralny, bądź przez samorząd terytorialny. O ile z natury rzeczy komercyjne zasady panujące w "urynkowionym” segmencie są dość czytelne (z grubsza rzecz biorąc rządzi tu prawo popytu i podaży), o tyle o wiele trudniej określić reguły gry obowiązujące w segmencie formalnie państwowym, faktycznie jednak 
Błąd Izokratesa (czyli o konserwatywnej polityce kulturalnej)

w znacznej części „wydzierżawionym” autonomicznym środowiskom i grupom interesu.

Współczesna wiedza o praktyce rządzenia nie pozostawia wątpliwości, że jedynie w weberowskiej „,biurokracji idealnej” następuje całkowite oddzielenie interesów publicznych i prywatnych (Kjaer, 2009, s. 29 i nast.). Tymczasem zjawiska, jakie zachodzą w realnych agencjach rządowych i instytucjach publicznych działających w sferze kultury, nie odbiegają od tego, co stało się typowe dla wszelkich współczesnych biurokracji, których misją jest dostarczanie usług na koszt publiczny. Następuje tu więc przede wszystkim proces „przechwytywania" owych teoretycznie państwowych agencji i instytucji przez środowiskowe grupy interesów, a mechanizm tego zjawiska dość precyzyjnie opisuje jedna z ekonomicznych „teorii wyboru publicznego", sformułowana przez George'a Stiglera (capture theory) (Wilkin, 2012, s.186 i nast.). Środowiskom „ludzi kultury" przychodzi to ze szczególną łatwością ze względu na ich uprzywilejowany status społeczny, rozległe stosunki towarzyskie, a często także medialną sławę, a co za tym idzie - wysoką zdolność wpływania na takie przekierowywanie funduszy publicznych, które odpowiada ich interesom. Jednym z symptomów tego zjawiska jest zgodny i zdeterminowany opór, jaki środowiska te stawiają wszelkim planom decentralizacji prowadzenia i finansowania instytucji kultury, gdyż plany takie grożą przecięciem albo co najmniej rozluźnieniem wieloletnich powiązań z biurokracją centralna, a tym samym nieformalnych "dojśćc do źródeł finansowania. Agencje rządowe, które zajmują się finansowaniem kultury, mają więc naturalną tendencję do daleko posuniętej emancypacji spod politycznego nadzoru, przez co tracą zdolność prowadzenia polityki kulturalnej państwa, stając się w gruncie rzeczy instytucjami o charakterze lobbystycznym, „podpiętymi" pod rządową biurokrację. Takiej emancypacji sprzyja głęboki rozbrat pomiędzy polityką i kultura, gdyż jego skutkiem opinia publiczna żywi mocne przekonanie, że interwencje ze strony państwa na polu kultury są nieuzasadnionym nadużyciem, a w konfliktach pomiędzy biurokracją i polityką a "ludźmi kultury" (dotyczących najczęściej niegospodarnego wydawania funduszy publicznych albo personaliów przy obsadzie stanowisk w instytucjach kultury) - jednoznacznie staje po stronie tych ostatnich, przeciwko państwu. Jeśli mechanizm „przechwytywania” uzyskuje w końcu także wsparcie 
oportunistycznych polityków, którzy dostrzegają w nim często własny interes wyborczy, tworzy się tzw. „żelazny trójkąt” (grupy interesu, biurokraci i politycy) albo - używając określenia Barry'ego Weingasta z Hoover Institution - „subrząd” (subgovernement), czyli „integralny i zautonomizowany polityczny układ wzajemnych zysków"(Weingast, 1981, s.153), który zastępuje i wyręcza państwo na polu polityki kulturalnej. Ów swoisty „układ” dość łatwo zyskuje sympatię ze strony opinii publicznej, która coraz bardziej nieufna wobec instytucji państwa zwykła jednak adorować swoich ulubionych aktorów, piosenkarki, literatów czy generalnie - „ludzi kultury”.

Dla całości obrazu trzeba jeszcze dodać, że coraz częściej ideologią takich „subrządów” jest „kultura sabotażu” (by przywołać termin Scrutona), i to niezależnie od tego jaki obóz polityczny sprawuje władzę i jakie poglądy na pożądany kształt kultury głoszone są przez dominującą politycznie większość. Ten fakt z pozoru może wyglądać na paradoks, nie jest nim jednak w istocie, jeśli zważyć, że jego rozsądnym wyjaśnieniem są racjonalne i egoistyczne interesy wszystkich partnerów takiego układu. W polskich warunkach podręcznikowym przykładem tego zjawiska może być tzw. „mecenat państwa" nad sztuką nowoczesną któremu towarzyszą w ostatnich latach wylobbowane wielkie publiczne inwestycje w nowe przestrzenie wystawiennicze (tzw. „muzea sztuki nowoczesnej”, które stały się wysuniętymi placówkami bojowymi „kultury sabotażu”). Pisał swego czasu artysta i krytyk Sławomir Marzec :

Dzisiejszy artworld wytworzył mechanizmy, które de facto skazują nas na akceptację durnoty, taniego cwaniactwa i bezczelności jako równoprawnych strategii kreowania sztuki. A że mamy demokrację i oficjalne pojmowanie sztuki jako manifestację form życia, to w zasadzie obok "Rembrandta i Duchampa” wisieć musi też wszystko inne (Marzec, 2016, s. 38-39).

To co w tej konkluzji uderza, to podkreślenie bezalternatywnej „oficjalności" takiego stanu rzeczy, czyli niemożliwej do zmiany polityki kulturalnej-ponadpartyjnej i odpornej na demokratyczną zmienność władzy.

5. Tym sposobem odsłania się nam nieoczywista na pozór prawda, że sama możliwość prowadzenia przez państwo polityki kulturalnej 
stanęła dziś pod znakiem zapytania, a w każdym razie, że owej możliwości nie możemy nadal traktować jako rzeczy bezspornej. Ideał „politycznego humanizmu” ma w dzisiejszych warunkach charakter radykalnej utopii, skoro rozziew pomiędzy cenionymi przez jednostki wartościami (niemal wyłącznie prywatnymi), a pogardzanym przez większość obywateli życiem publicznym jest tak wielki, jak rzadko kiedy w historii. Jest zapewne paradoksem fakt, że dzieje się tak w czasach, w których demokratyczne państwa uznały kulturę za jeden z działów własnej administracji, w efekcie czego zajmują się nią zawodowo setki (albo i tysiące) płatnych funkcjonariuszy publicznych. Rzecz jasna możliwe jest podejmowanie przez władze publiczne interwencjonistycznej polityki kulturalnej, wedle modelu stworzonego niegdyś przez Izokratesa. Warto jednak mieć na uwadze, że tamta próba odtworzenia w Atenach Areopagu, jako „władzy dozorującej państwa” nad kultura, nie powiodła się, a sam autor owej koncepcji za jakiś czas popadł z tego powodu $\mathrm{w}$ tak wielkie rozgoryczenie, że stał się zdeklarowanym zwolennikiem „likwidacji” swej popsutej ojczyzny i wcielenia jej do rodzącego się imperium macedońskiego. Najprawdopodobniej nie mogło stać się inaczej. Na konstruktywistycznego konserwatystę (takiego jak Izokrates), pragnącego za pomocą interwencji państwa przywrócić utraconą przez wspólnotę harmonię polityki i kultury, czyha bowiem pułapka odrzucenia i śmieszności. Tak się dzieje zwłaszcza wtedy, gdy próbuje on użyć władzy i autorytetu państwa (albo stanowionego przez państwo prawa) do wyegzekwowania dawnych reguł postępowania obywatela we wspólnocie, które jednak utraciły już kulturową moc i ważność. Zabawnym, ale poniekąd wzorcowym przykładem takiej sytuacji mogą być nie tak dawno stworzone przez konserwatywny rząd w Polsce nowe podstawy programowe dla szkół publicznych, w których zaleca się m.in., aby uczeń:

słuchał uważnie i z powagą wypowiedzi osób podczas uroczystości, przedstawień i obchodów świąt narodowych, przyjmując postawę skupienia (...), wyczuwał ich nastrój i przyjmował adekwatne zachowania, np. śmiał się z usłyszanych dowcipów, zachęcony włączał się do wspólnego skandowania i śpiewania (Rozporządzenie Ministra Edukacji Narodowej z dnia 14 lutego 2017 r.). 
Wszystkie wskazane w tej instrukcji sposoby zachowania uczniów młodszych klas są oczywiście rozumne i „wspólnototwórcze”. Pomimo to muszą sprawiać wrażenie parodii, jeśli nie płyną już z żadnej realnie istniejącej „harmonii człowieka i polis” (by jeszcze raz odwołać się do Jaegera), ale mają zostać sztucznie i mechanicznie zaprowadzone z inicjatywy władzy publicznej.

Ten błahy w sumie casus wyraziście obnaża prawdziwą trudność interwencjonistycznej polityki kulturalnej. Trudność tę powiększa jeszcze fakt, że samo demokratyczne państwo (które miałoby być rozumnym podmiotem takiej polityki) zyskało współcześnie formę quasi-rynkowa gdyż - jak przekonująco pokazał to już Anthony Downs (Downs, 1957, s. 21 i nast.) - dawna opinia publiczna upodobniła się do rynku, na którym partie polityczne, chcąc zdobyć władzę, muszą zachowywać się jak krzykliwi wschodni kupcy, starający się zwrócić uwagę jak największej liczbie przechodniów na swoje kramy. Permanentny populizm, happening i skandal, które rządzą konkurencją o władzę polityczna, upodobniły życie publiczne do showbiznesu. Każda zatem państwowa interwencja na rynku kultury jest ex definitione podejrzana o to, że ma służyć podporządkowaniu logiki „normalnego” rynku, na którym chodzi o zarabianie pieniędzy na produkcji kulturalnej, innej, ale również „rynkowej” logice, wedle której toczy się konkurencja o władzę. Współczesne partie polityczne instrumentalizują niemal całą otaczająca je rzeczywistość względem własnej taktyki konkurowania o zdobycie lub utrzymanie władzy. Zasadne zatem jest pytanie: jakaż to wyższa racja miałaby sprawiać wyłączenie spod tej reguły dziedziny kultury? I to tym bardziej, że właśnie na tym polu stosunkowo łatwo zyskać nawet znaczną polityczną przewagę konkurencyjną, za pomocą prostych i ubogich środków.

6. Polityczna roztropność wymaga więc sformułowania swego rodzaju „reguły ostrożnościowej”, dotyczącej prowadzenia w dzisiejszych warunkach przez państwo konserwatywnej polityki kulturalnej. Najprościej taką regułę można by sformułować następująco:

W sytuacji gdy ryzyko interwencji władzy publicznej na polu kultury jest rozległe, a perspektywa efektów raczej wątpliwa, cele polityki kulturalnej winny być dobierane punktowo i angażować za każdym razem znaczny potencjał państwa. 
Błąd Izokratesa (czyli o konserwatywnej polityce kulturalnej)

Podejście tu proponowane jest oczywiście odmienne od neoizokratejskiej strategii "kulturalnego etatyzmu”, wedle której należałoby dążyć do ustanowienia „władzy dozorującej państwa” w dziedzinie kultury oraz obarczyć ją misją wypierania (gdzie tylko się da) reguł rynkowych i wtłaczania w to miejsce aktywności władzy publicznej (i to najlepiej od razu na poziomie centralnym). Kulturalny etatyzm w swej czystej formie to nic innego, jak ponowiony błąd Izokratesa, być może nieoczywisty u końca greckiej epoki klasycznej, ale najzupełniej ewidentny we współczesnych warunkach kulturowych i politycznych. W odniesieniu do tych współczesnych warunków szczególnie trafna pozostaje bowiem uwaga poczyniona przez Jaegera, iż:

nie można ukształtować prawdziwie twórczych sił za pomocą programu wychowawczego tego lub innego reformatora, muszą one wypływać z charakteru społeczności i epoki; natomiast kiedy kultura upada, ta obiektywna, bezosobowa paideia istnieje jedynie w sensie negatywnym, jako „zepsucie” szerzące się od całości ku każdej oddzielnej części (Jaeger, 2001, s. 1033).

Wysiłek ów jest jeszcze bardziej daremny w takim czasie, kiedy urynkowiona polityka poddała się panowaniu marketingu i próbuje wprząc w ów kołowrót także kulturę; kiedy „anty-rozum” zawładnął już w znacznym stopniu przestrzenią publiczną i rozsądza, co należy do sfery poprawności, a co poza nią wykracza; i kiedy wiele spośród instytucji państwowych zostało trwale "przechwyconych" przez lobby „ludzi kultury”, czyli bezpośrednich interesariuszy polityki kulturalnej. Całkiem wbrew intencjom „kulturalnych etatystów", ich doktryna, zastosowana dziś w praktyce państwowej, ma wszelkie szanse, aby pogłębić współczesną przepaść pomiędzy polityką i kulturą oraz przyspieszyć postęp „zepsucia”, o którym pisze Jaeger.

Proponowana tu reguła ostrożnościowa pozostawałaby natomiast w zgodzie ze współczesną wiedzą o państwie, świadomą kontradykcji pomiędzy rozległością funkcji państwa i jego siłą. Przypadek polityki kulturalnej jest $\mathrm{w}$ tej mierze odbiciem prawidłowości, znanych choćby z polityki gospodarczej czy społecznej. Francis Fukuyama jest autorem prostej macierzy, która poszczególnym państwom przyporządkowuje ich swoistą „miarę państwowości”, posługując się dwoma wyróżnikami: zakresem funkcji państwa i jego potencjałem 
(capacity). Ów „potencjał” Fukuyama rozumie zdroworozsądkowo, jako konglomerat

zdolności do formułowania i wdrażania polityki, administrowania w sposób efektywny i przy pomocy minimalnej biurokracji, kontrolowania przekupstwa, korupcji i łapownictwa, utrzymywania wysokiego poziomu przejrzystości instytucji, oraz, co najważniejsze, egzekwowania prawa (Fukuyama, 2005, s. 24).

Polską współczesną „miarę państwowości” wyznacza średni (na tle Europy) zakres funkcji państwa, a zarazem niski potencjał. Dość często możemy doświadczać tego, jak państwo „walczy” na wielu frontach, ale $\mathrm{z}$ reguły okazuje przy tym daleko idącą nieudolność. Bierze się to $\mathrm{w}$ znacznym stopniu $\mathrm{z}$ braku struktur i procedur, pozwalających na formułowanie strategii ogólnopaństwowych oraz ich skoordynowaną egzekucję (Rokita, 2015). Dla racjonalnego interwencjonizmu kluczowa jest więc umiejętność selekcji i ograniczenia liczby pól bitewnych oraz zdolność zaangażowania maksymalnie dostępnego potencjału państwa na tych polach. Bitwy te będą się kończyć porażkami, jeśliby miałyby być prowadzone na peryferiach polityki państwowej, bez udziału głównych ośrodków władzy oraz na poły amatorskimi albo wąsko „resortowymi” siłami, bez mocnej koordynacji poziomej.

7. Wybór priorytetowych celów interwencji państwa na polu kultury jest $\mathrm{w}$ ostatecznym rachunku kwestią politycznej aksjologii. Tym niemniej, wydaje się, że z perspektywy rozumu dwa cele można bez większych kontrowersji uznać za odnoszące się do samych podstaw egzystencji wspólnoty politycznej. Są to: utrzymanie elementarnej spójności duchowej wspólnoty, tak by nie ulegała ona powolnej rozsypce, oraz reprodukcja narodowej elity kulturalnej, czyli grupy „odbiorców wytworów intelektu i sztuki” (by skorzystać z prostej definicji Eliota; tenże, 2007, s. 147), której społeczną funkcją jest przekaz narodowej kultury, a więc pośrednio - zachowanie ciągłości bytu wspólnoty. W ambicji oddziaływania na dusze i umysły obywateli konkurentem państwa na obu tych polach jest rynek, tyle tylko, że potencjalne relacje państwa i rynku na każdym z nich bynajmniej nie są tożsame. W dziele budowania wspólnoty możliwa jest bowiem swego rodzaju „zmowa konkurencyjna” państwa i rynku, 
Błąd Izokratesa (czyli o konserwatywnej polityce kulturalnej)

a produkcja rynkowa nie tylko może być sojusznikiem państwa, ale nawet powinna „wyręczać" je w misji wzmacniania w masach poczucia przynależności do wspólnoty. Jest bowiem całkiem jasne, że pogardzana przez lud współczesna polityka nie ma szans zdobyć choćby ułamka tego wpływu na uczucia mas, jaki posiadają dziś produkcje showbiznesu. Dobrze zatem, by państwo umiejętnie inspirowało taki sojusz i chciało być „wyręczane” na tym polu przez rynek. Jest dokładnie odwrotnie, gdy idzie o budowę (czy odbudowanie?) instytucji publicznych, których misją winna być reprodukcja narodowej elity. Zglobalizowany rynek dokonuje na tym polu w ciągu ostatnich lat prawdziwych spustoszeń, zaniżając poprzez masowość kształcenia standardy edukacyjne, sprowadzając wykształcenie do potrzeb produkcyjnych i przekształcając uniwersytety w komercyjne firmy. Nie znaczy to bynajmniej, że urynkowione kształcenie nie jest dobrą (a być może nawet najlepszą z możliwych) metodą powszechnego, mało kosztownego i społecznie przydatnego kształcenia mas. Rzecz tylko w tym, że uchylenie tej reguły w odniesieniu do kształcenia elity stanowi w istocie warunek dziedzicznego przekazu kultury, a co za tym idzie - samej możliwości istnienia wyższych form kultury narodowej na przyszłość. Pisał Eliot:

Jak sądzę, nikt nie będzie podawał w wątpliwość faktu, że w każdym przyszłym społeczeństwie, podobnie jak $\mathrm{w}$ każdym cywilizowanym społeczeństwie w przeszłości, muszą istnieć różne kulturowe poziomy (...). Jeśli więc jest dla kogoś czymś szokującym, że kultura i egalitaryzm powinny pozostawać w sprzeczności - to nie proszę by zmienił swoją wiarę. Proszę tylko, by przestał składać słowne deklaracje dotyczące kultury (Eliot, 2007, s.127 i 117).

Warto przy tym zauważyć, że autor tych słów był zdecydowanym przeciwnikiem elitarystycznych teorii kultury (np. Karla Mannheima), wedle których istnieją "grupy kulturotwórcze" , które są wyłącznymi twórcami i odbiorcami kultury. Eliot wierzył w taki model kultury narodowej, który charakteryzuje z jednej strony powszechność, z drugiej zaś zróżnicowany udział różnych grup społecznych, a także silne oddziaływanie kulturowe owych grup na siebie nawzajem, dzięki któremu buduje się naród. Definiując dwa sformułowane powyżej fundamentalne cele polityki kulturalnej w kategoriach instytucjonalnych, można by powiedzieć, że jej 
skuteczne prowadzenie wymaga istnienia dwóch nowocześnie zorganizowanych i świadomych swojej misji instytucji publicznych: "Agencji Integracji Wspólnoty" oraz „Agencji Reprodukcji Elity”.

Szczególna doniosłość tych dwóch funkcji polityki kulturalnej bierze się stąd, że obie są $\mathrm{w}$ istocie próbą budowania zetatyzowanej (niestety z konieczności) pseudo-paidei, w warunkach kulturowych, w których prawdziwa paideia nie jest już możliwa, gdyż została wyparta przez wszechogarniającą negatywną „paideneie”, czyli „,zepsucie szerzące się od całości ku każdej oddzielnej części" (jeszcze raz przywołując terminologię Izokratesa i Jaegera). Owa pseudo-paideia to jedyny w istocie środek, za pomocą którego państwo może jeszcze, co prawda w dość ograniczony sposób, oddziaływać na dusze i umysły. Nie wynika z tego bynajmniej, aby polityka kulturalna nie miała mieć na oku także innych funkcji, nie aż tak politycznie doniosłych. Warto pośród nich wymienić zwłaszcza dwie, w których - $\mathrm{w}$ ten bądź inny sposób - rynek powinien być istotnym sojusznikiem państwa. Jedną z form politycznej rywalizacji państw w stosunkach międzynarodowych jest dziś skoordynowany wysiłek promocji państw, miast i regionów, w którym kwestie kultury odgrywają rolę pierwszoplanową. W Polsce dobrym przykładem jest w tej mierze inwestycyjny sukces Krakowa, dla którego kluczową przesłanką stał się „,argument o kulturze” (Mehra, 2017). Oczywistą funkcją polityki kulturalnej państwa winna być także dbałość o wprowadzanie standardów „dobrego rządzenia” do publicznych instytucji sektora kultury. Tutaj z reguły najpoważniejszym przeciwnikiem jest lobby „ludzi kultury”, które najczęściej próbuje „przechwycić" owe instytucje, pod pretekstem wspólnej z rządem walki przeciw komercjalizacji kultury. Tymczasem rynek jest oczywistym sojusznikiem rządu, gdyż wymaga przejrzystości procedur, rozbijania koterii, mierzenia kosztów i efektów oraz zarządzania przez rezultaty. Właśnie z rynkowej logiki bierze się anglosaski koncept reformowania instytucji publicznych, zwany "nowym zarządzaniem publicznym” (NPM) (Zawicki, 2011). Z perspektywy polityki kulturalnej szczególną zaletą rynku jest to, że znacznie trudniej niźli klasyczna biurokracja, poddaje się on zwichnięciu przez stosunki nieformalne i towarzyskie, a te stoją nazbyt często u źródeł deformacji agend i instytucji państwowych, działających w sferze kultury. Można by nawet powiedzieć, że swoista gra z rynkiem, jaką starają 
się w różnych krajach prowadzić konserwatywni liberałowie, polega właśnie na tym, aby „używać” rynku jako mechanizmu ograniczającego nadmierne wpływy interesariuszy polityki kulturalnej. Tym sposobem państwo może choćby po części odzyskiwać utraconą na ich rzecz podmiotowość i samosterowność.

8. Podsumowując. Powyższe siedem uwag na temat polityki kulturalnej winno zostać potraktowane jako "tezy do dyskusji”. Nie wynikają one (mówiąc kolokwialnie) jedynie „z książek”, ale przede wszystkim z politycznego i biurokratycznego doświadczenia autora. To doświadczenie skłania właśnie do daleko posuniętego sceptycyzmu co do efektów sui generis „entuzjazmu administracyjnego” w ogólności, a zwłaszcza w zastosowaniu do domeny kultury. Sceptycyzm ów ma tym silniejsze umocowanie w państwie takim jak Polska, tzn. państwie chronicznie źle zorganizowanym. Ani władza państwowa, ani partie, ani urzędy nie mają mocy ożywienia prawdziwej paidei i tu tkwi sedno błędu jaki popełnia "etatysta kulturowy”, pragnący "odbić" kulturę na rzecz państwa i polityki. Zarazem jednak autor jest niemal pewien, że państwo nie jest jeszcze całkowicie bezradne na polu kultury, pod warunkiem, że zechce i będzie umieć skoncentrować cały swój potencjał na nielicznych długofalowych celach, najważniejszych dla przyszłego losu wspólnoty. Tego rodzaju interwencjonizm wymagałby jednak zarówno sporej politycznej odwagi, jak i przede wszystkim bardzo w Polsce deficytowej sztuki budowania i reformowania instytucji. W tej kwestii starożytni okazali wielką przenikliwość, sądząc iż „duszą państwa jest jego ustrój”. W takim przedsięwzięciu rynek może być raz przeciwnikiem, a raz przyjacielem państwa. A w każdym razie biurokratyczne państwo, prowadząc z rynkiem swoistą grę, może się odeń wiele nauczyć.

\section{Bibliografia}

Downs, A. (1957). An Economic Theory of Democracy. New York: Harper. Eliot, T.S. (2007). Ku definicji kultury [w:] Chrześcijaństwo, kultura, polity$k a$. Warszawa: Wydawnictwo Uniwersytetu Warszawskiego.

Fukuyama, F. (2005). Budowanie państwa. Tłum. J. Serwański. Poznań: Dom Wydawniczy Rebis. 
Hegel, G.W.F (1958). Wykłady z filozofii dziejów. Tom II. Warszawa: PWN. Isocrates (2012), Aeropagiticus. eBook. Charles River Editors.

Jaeger, W. (2001). Paideia. Formowanie człowieka greckiego. Warszawa: Fundacja Aletheia.

Kjaer, A.M. (2009). Rzadzenie. Warszawa: Wydawnictwo SIC!

Marzec, S. (2016). Alibi dla ciemnoty. Rzeczpospolita, Plus Minus, 29 października 2016.

Mehra, S. (2017). Kraków to doskonały wybór, Rzeczpospolita, nr 6 (10644), 8 stycznia $2017 \mathrm{r}$.

Minister Edukacji Narodowej (2017). Rozporządzenie z dnia 14 lutego 2017 „Nowa podstawa programowa dla szkół publicznych".

Rokita, J. (2015). Zbudować państwo. Dwadzieścia idei na rzecz poprawy jakości rządzenia. Raport Centrum Analiz Klubu Jagiellońskiego. Kraków: CAKJ.

Rorty, R. (1999). Obiektywność, relatywizm i prawda. Warszawa: Fundacja Aletheia.

Wilkin, J. (2012) (red.). Teoria wyboru publicznego. Warszawa: Wydawnictwo Naukowe Scholar.

Weingast, B.R. (1981) Regulation,reregulation and deregulation: The political foundation of agency clientele relationship, s. 153. Pozyskano z: http://scholarship.law.duke.edu/cgi/viewcontent.cgi?article $=3611 \&$ context $=$ lcp Zawicki, M. (2011). Nowe zarzadzanie publiczne. PWE: Warszawa.

\section{Copyright and License}

This article is published under the terms of the Creative Commons Attribution - NoDerivs (CC BY- ND 4.0) License http://creativecommons.org/licenses/by-nd/4.0/ 